\title{
Instances of Agency: Julio Cordero's Archive and Photographic Portraits
}

Jorge Coronado

Northwestern University

\begin{abstract}
In this article, I discuss the notion of agency in relationship to Julio Cordero's photographs. Julio Cordero (1879-1961) owned a photography studio in La Paz in the first half of the twentieth century and produced an array of images both inside and outside of the studio. I also offer a sense of the rich documentation that exists in the complete Cordero archive as well as the insights that it opens up concerning the interventions in self-representation made possible by photographic portraiture. Essentially, these interventions lead us to conceptualize image culture as a prime space for enacting agency in Bolivia and Latin American more broadly.
\end{abstract}

\section{Keywords}

Photography, portrait, agency 


\section{Resumen}

En este artículo discuto la noción de agencia en relación con las fotografías de Julio Cordero (1879-1961), que durante la primera mitad del siglo XX fue propietario de un estudio fotográfico en La Paz y produjo una serie de imágenes tanto dentro como fuera del estudio. El artículo también ofrece un abordaje a la rica documentación que existe en el archivo completo de Cordero, así como a los conocimientos que se abren en relación con las intervenciones en la autorrepresentación que el retrato fotográfico hace posible. Esencialmente, estas intervenciones nos llevan a conceptualizar la cultura de la imagen como un espacio privilegiado para la viabilización de agencias culturales en Bolivia y en América Latina en general.

\section{Palabras claves}

Agencia, fotografía, retrato

Recently, the Oficialía Mayor de Culturas of the city of La Paz announced the purchase of 17,000 images from the Cordero archive, in order that it become "patrimonio cultural" available to paceños and presumably all, at first online and eventually at a dedicated museum of photography (Anonymous). The new site and coming opening of the Museo Archivo Fotográfico Ciudad de La Paz was announced in 2014, and currently the project seems to be awaiting funding in order to proceed (Saavedra, Cazas). While the promise of the conservation of part of the archive is laudable, it is pressing that all documents and images related to Cordero's work be preserved. The photographer Julio Cordero Castillo's archive, including but in no way limited to these 17,000 pictures, stands out among the many extraordinary examples of Andean photography of the early twentieth century. Known simply as Julio Cordero, the photographer's work is much valued for what one might denote as usual reasons: the refined technical work, the array of images, the long period of productivity. In all these arenas, Cordero's work is outstanding.

But it is the combination of both visual images as well as business documents in Cordero's archive that is unusual for Andean photography and in fact rare enough to make it unique, to my knowledge, for the study of early twentieth century photographic portraiture in the region. In the most basic 
sense, Cordero's archive presents researchers with a remarkable opportunity not only to understand the wide and complex business dealings that photography generated both inside and outside the studio, but also the way in which the production of images itself was inseparable from those dealings. Although insufficiently studied, the impact of consumption of photographic images as well as the emergence of the agency of social subjects through it embodies a-perhaps the-fundamental significance of photography in early twentieth-century Latin America. In this article, I will discuss the notion of agency in relationship to Cordero's photographs. I will also offer a sense of the rich documentation that exists in the complete archive as well as the insights that it opens up concerning the interventions in selfrepresentation made possible by photographic portraiture. ${ }^{1}$ Essentially, these interventions lead us to conceptualize image culture as a prime space for enacting agency.

Almost any image taken from Cordero's portraits illustrates this concept. For example, image 1, probably taken around 1930, shows a well-dressed woman against a cloudy background. She stares directly at the camera. In elaborating the image, we note that several choices, such as format, background, physical support, and technical aspects such as lighting, were likely offered and elaborated by the photographer. But the image itself also has several features, especially those having to do with posture and dress that are most likely in the realm of the sitter's determinations. The lavish and likely imported coat, for instance, as well as the luxurious earrings and necklacethe latter seemingly placed outside her clothes so that it cannot be ignoredare choices that she made in preparation for the session. Moreover, the neatly coifed hair highlights and emphasizes the face, as does the dramatic shading that Cordero orchestrated. That shading lends gravity and a penetrating quality to her gaze, which she holds almost haughtily. It is an image that insists on the presence and self-possession of the sitter. Her choices, posture, and countenance play no small part in achieving this effect.

\footnotetext{
${ }^{1}$ For related discussions on Cordero and Andean photography, see my book Portraits in the Andes.
} 


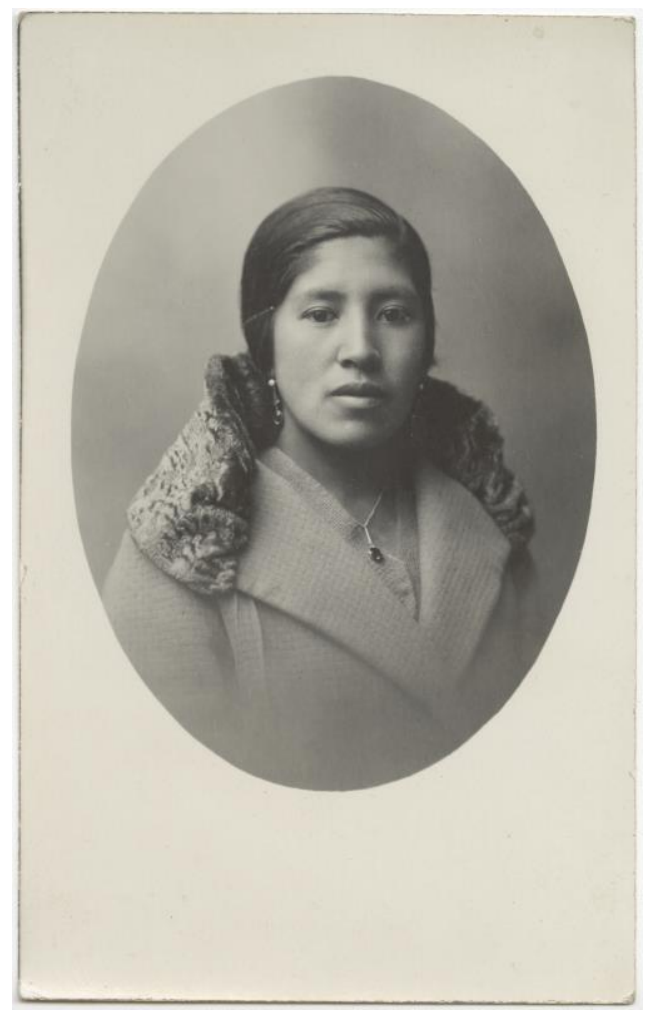

Image 1: Julio Cordero, La Paz, circa 1930

Source: Cordero Archive

Notions of agency have often been elaborated through sociological methods. Michel de Certeau's The Practice of Everyday Life, originally published in French in 1980, studied and theorized the way in which people use the objects and spaces with which they come into contact on a daily basis in order to appropriate them as a means of negotiating their specific sociohistorical contexts. Based on fieldwork, the text conceptualizes how "regular" people intervene in everyday life, from consuming to inhabiting urban space, in order to resemanticize what they receive from industry and the state. Moreover, the text contains a remarkably sensitive description of 
scholarship's intervention into the description of these practices. Because of this, a quotation from that text will help me propose some keys to understanding Cordero's portraiture, and by extension all such images:

It is the study itself which is marginal with respect to the phenomena studied. The landscape that represents these phenomena in an imaginary mode thus has an overall corrective and therapeutic value in resisting their reduction by lateral examination. This return to another scene thus reminds us of the relation between the experience of these practices and what remains of them in an analysis. It is evidence, evidence which can only be fantastic and not scientific, of the disproportion between everyday tactics and a strategic elucidation. Of all the things everyone does, how much gets written down? Between the two, the image, the phantom of the expert but mute body, preserves the difference. (de Certeau 41)

Perhaps the most difficult challenge in studying portraits is resisting the temptation to narrativize what they image. Creating stories around images is the case in the presence of the facts that history, archives, and informants afford us; but it is especially strong, curiously, when faced with photos one knows little about, in the presence of likenesses that are perfectly visible and discernible and yet have no name, no other singularity but their visible materiality. This impulse to wonder about what it is that we see arises in the case of any photograph. But it is especially problematic and challenging in attempting to communicate an understanding of both the contextual circumstances of production and what the photographs may mean in terms of the very subjects that on the one hand originate them and on the other produce them. This is because, in the narrativizing that photographs are often the basis for, statements and presuppositions about the subjects photographed are invariably made. These statements and presuppositions can be and often are historical in nature, and thus seek to assign - but they do so in the language of discovery and analysis - the self-determination of human subjects and groups before particular sociohistorical contexts. As such, the issue becomes one of how to discern agency through portrait images or, in any case and perhaps preeminently, how not to erase the agency of others through a critical reading.

An example of such an inscribing of narrative onto photographic portraiture is the commentary that accompanies images in Cordero's book Estudio Archivo Cordero: Bolivia 1900-1961. The book is an important contribution to the study of historical photography in Bolivia. It offers a wide 
range of finely reproduced images from his archive, among which portraiture predominates, although other forms such as mugshots are also included (Cordero). Most if not all images have captions assigned to them by the editors. While the captions certainly animate what we might see, they do so from the peculiar perspective of the editors. Shame, pride, avarice, and jealousy, among other motives, seem to be assigned in order to highlight the ethical dimensions of the pictures but especially of the society from which they originate. As an intervention itself, the editing and captioning of the book's photographs tend strongly toward a critique of colonial and gender relations in modern Bolivian history. However, the agency expressed is that of the editors. These expressions make it difficult to perceive any such ability in the photographed subjects themselves, as they literally overwrite the sense that the images create through bodily and other visual registers. Moreover, mugshots are treated in quite the same way as portraits made to order, thus collapsing the significant differences in these two modes of producing a visual representation.

With respect to this issue and returning to de Certeau, The Practice of Everyday Life is instructive. The author accounts for both the compromised and compromising location of the site of enunciation of the scholarly work, or "lateral examination" as he terms it, even as he suggests within it another, more fecund practice, one that invokes imagination so as to be able to evoke the "image" that represents the difference between what gets recorded about experience and experience itself. In this way, de Certeau describes the limitations of scholarship and does so in relationship to the experience that it attempts to describe, but also with recourse to a more obscure third term, "the expert but mute body." By the latter, the French critic means to designate a site for the preservation of interventions into daily life by subaltern subjects. This difference is characterized as differential. In other words, crucially, whatever the expert body records must necessarily be understood in its distance to scholarly analysis, and not through the optic of the latter. The possibilities for our understanding of portraiture concern this third term and the ways in which we might understand it as an "image." In photographic portraiture and as the portraits studied here evidence, the body becomes an image.

In our discussion, the term "image" is of interest because of the contrast with respect to the competence to preserve experience between languagewhether oral or written-and the visual. On the one hand, de Certeau is affirmative in preserving the role of analysis as a key way in which we can 
access that "landscape" of human activity that surrounds us. On the other hand, he is cautious to delineate the significant limitations of language's ability-that is, the "lateral examination" that scholarship can be-to evoke and explain that landscape. And while the assertion that everything not captured in scholarly analysis is preserved in the "image" may be taken as an overly hopeful or idealistic assertion concerning the preservation of subaltern culture, it may also be understood as a gesture of acknowledgment toward the preponderance of visual modes among modern cultures. Let me be clear: I am not arguing that photography or portraiture is the object to which de Certeau is concretely referring to in his study. I am, however, insisting that the images to which he refers, in ways that exceed lettered representation, are able to record significant dimensions of everyday life and subjects' negotiations of it.

The characterization of a visual realm in which daily experience is captured is compelling precisely because it insists on this register as a prime site for the preservation of subaltern activity. Importantly, de Certeau's characterization may also be a way of contradicting positions such as that of Guy Debord, whose idea of the spectacle rested on a notion, prevalent by that time, of the inertness of the mass (Debord). In Debord's conception, that mass was coincident with subaltern populations. ${ }^{2}$ De Certeau thus revalorizes the visual field in terms of its richness as a tool for capturing experience. Key to this visual field is the corporality that inhabits it and is the degree zero of subaltern tactical interventions.

For the study of portraiture, de Certeau's articulation of the relative poverty of scholarship in relation to the breadth of subaltern experience lies in its implicit warning that scholarship can never adequately represent that experience. Therefore, and because a critical approach cannot exhaustively explain portraits, it must instead work in an imaginative mode, which is evocative of that large but inaccessible experience. In this way, the commentary on photographs as an index of a historical moment and of subjects' self-determination in it represents the "lateral" examination that de Certeau describes. Moreover, it is my contention that "the image, the phantom of the expert but mute body," appears in portraits, even if only briefly, but

\footnotetext{
${ }^{2}$ One of de Certeau's most important interlocuters is Guy Debord. It is not surprising that in his account of the agential interventions committed by the common man on a daily basis, de Certeau critiques notions, such as Debord's, that rest upon "the assumed passivity of the consumer." Nor is it any wonder, in terms of the arguments presented in this study of photography, that de Certeau contraposes the term "image" (de Certeau, xxi) to Debord's "spectacle" (Debord).
} 
cannot be identical to these objects. That is, precisely because photography is a trace of the real due to its indexical nature, it must be understood as a cultural practice that concretizes the body in a moment in time even as this very act represents, in the case of portraiture, a moment in agential subjectivity. Thus this moment of an agential trace as the body itself that the photograph somehow-but unmistakably-communicates must be understood in the full light of the subjectivity that created it. Moreover, following de Certeau, this trace must also leave evidence of the institutions in, through, and against which such subjectivities enact their agency or tactics in de Certeau's terminology.

The social scientist Guy Poitevin has been eloquent on this point. According to him, we should "understand by subaltern agency a range of cultural strategies that counter those processes of internalization which are at the root of the subordination of the subaltern and which secure a safe social reproduction of the hegemonic systems of representations and conduct." In this way, agency can be read across a large number of practices that are not necessarily revolutionary or rebellious, but rather disrupt or appropriate subordinating norms. Properly, this takes place within culture: "The sphere of the cultural is here guided by a concept of cultural conceived as an inalienable capability of semantic reappropriation and the practical challenging of normative idioms" (Poitevin 18). Poitevin's study focuses on peasant women in India, but his propositions illuminate the Andean case as well. I draw attention to Poitevin's characterization of an "inalienable capability" that I believe animates the Andean image culture described here. The critic of photography Julia Hirsch has put it succinctly: "By providing the means by which the poor could see themselves preserved, photography also allowed them to acquire a visual history. The rich had always been able to afford portraits and could surround themselves with painted or sculpted kin. Photography permitted an unprecedented range of people to look at relatives whom either time or space had taken from them" (Hirsch 44).

I would argue that every instance of photographic portraiture allows such readings. Consider, for example, the photograph in image 2 , taken by Cordero sometime around 1930. Cordero was a prominent studio photographer of Aymara origin who from 1900 to well into the 1950s ran a flourishing business in the center of La Paz. (Suárez 112-13) The popularization of the technology, and in particular its diffusion among both professionals and amateurs, seems to have led to a decrease in the profitability of his practice over time, but this image is from his studio's heyday. 


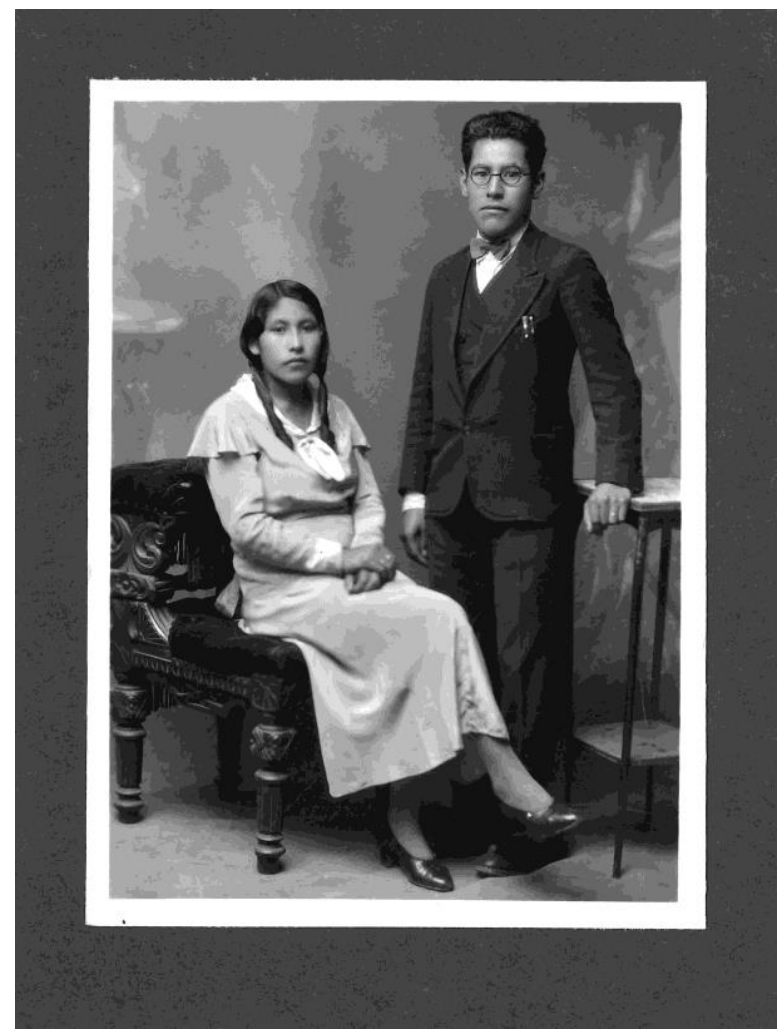

Image 2: Julio Cordero, La Paz, circa 1930

Source: Cordero Archive

It is a usual sort of portrait in many ways. First, typically for Cordero, his archive contains an abundance of such images, of individuals, couples, and families. They were the bread and butter of his practice. We know from his records and from interviews with living family members that Cordero's business was based mostly on portraiture with the occasional sally into police work as well as postcard production. His dealings included many other activities beyond the taking of photographs, as I will discuss shortly. While it is unknown just how many portraits he took over more than fifty years of 
practice, the extant collection of about 100,000 prints and negatives would seem to indicate quite a large number (Cordero Benavides).

The portrait is typical from the perspective of the conventions it enacts, although with some role reversals. The standing wife and sitting husband in a three-quarter pose hark back to a long-standing tradition in Western portraiture, and more particularly the standard photographic inclusion of the backdrop as well as the set piece of furniture can be found in portrait photography from its inception. The very existence of such a type, of a constructed image in the language of a long-standing pictorial idiom in which presumably the photographer would have had much invested, favors the idea of the photographer as producer, as the one who composes and manages the material and the light that makes it possible. Perhaps in this case all the more, given that the convention is reversed: it is the woman who sits and the man who stands.

In viewing images such as this one, we must also take into consideration the dress and postures in them, which of course are attributes of the bodies in the image. This photograph, for example, contains the relative harmony of dress between the man and woman, both of whom wear clothes that might be called urban or modern, that is, that deny a sharp contrast between the indigenous- and rural-associated dress of women and the entirely urban and Western dress of men as seen in many contemporaneous portraits in the region. Interestingly, and in the face of the carefully constructed and harmonious unity that is echoed in posture, the balance of the two bodies, and details like the identical wedding rings, the photograph prominently displays the woman's pigtails on either side of her head. At first glance, these are easily mistaken for the braids common amongst indigenous women and especially cholas. But the pigtails are unbraided, and twist elegantly down her shoulders. As such, the detail evokes indigeneity without confirming it. In some sense, the women's pigtails provide a visual counterpoint to the man's eyeglasses and even his pens, which ally his maleness, in a typical association, with Western culture. Her hairstyle belies her Western dress by reminding the viewer of continuities with other sectors of society in Bolivia and La Paz. Certainly, these can and should be understood as individual choices related to the particular ways in which male and female genders in the Andes chose to project a selfimage. In this way, the most probably married couple produces a meaning concerning their link to both Western and indigenous identities that is facilitated by the photographer but is not likely to originate in him. 
Similarly, Cordero's group portraits also create meaning through the orchestration of bodies and dress in a visual field. What does the cohesion of a group consist in, and how does a visual space become an appropriate site for it? Image 3, taken in La Paz, lets us see how repetition in a space creates the identity of the group, even as the preponderance of particular visual motifs, such as the bowler hats and skirts, but also the expansive fields of white that these create, allow for the dominance of one particular group within the portrait. In it, the women and children, who wear the same color, have been placed in the foreground. Moreover, women wearing dark colors have been placed in the background, as have all the men. Thus, while the portrait faithfully captures the semblance of all the figures who are included in the picture, it favors a particular subset and, interestingly, does so by shuffling off to one side those figures who in society would have a position of dominance.

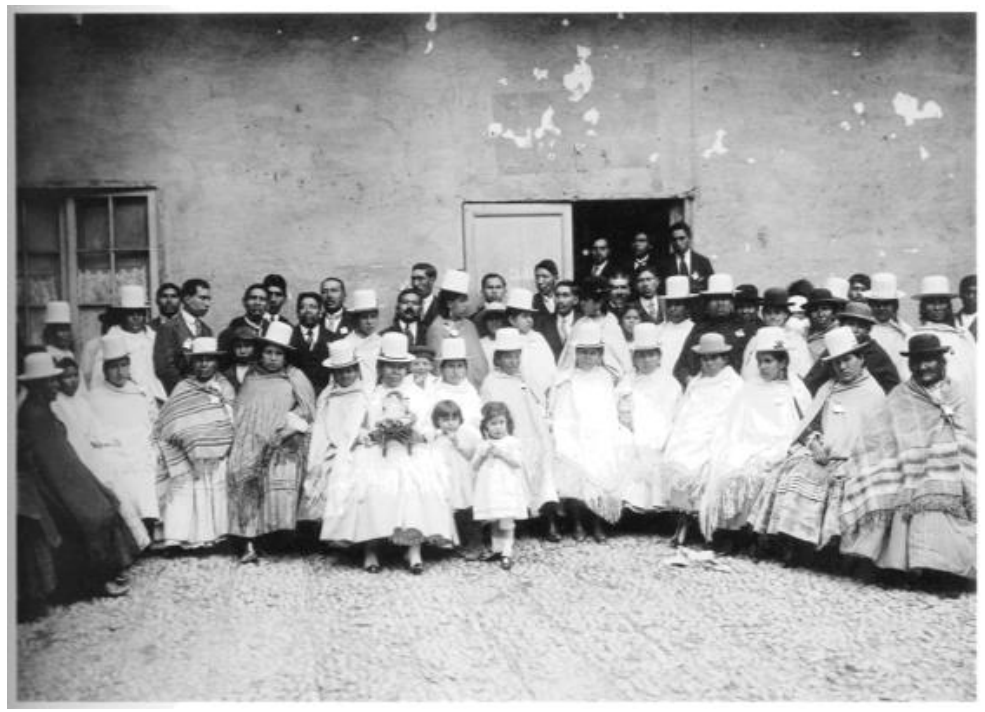

Image 3: Julio Cordero, La Paz, circa 1930

Source: Cordero Archive 
The Bolivian historian Rossana Barragán, in considering the history of mestizaje across the colonial period and into the twentieth century, has said of the early decades of the latter: "Ya a principios del siglo XX, volviendo a La Paz, el censo nos muestra que la ciudad tenía casi equitativamente la misma población indígena, mestiza y blanca (38\% de españoles, $28 \%$ de mestizos, y $30 \%$ de indígenas). Sin embargo, ya era difícil el reconocer a los mestizos, sobre todo hombres. Los responsables del censo de 1909 decían, por ejemplo, que los mestizos se vestían a la manera occidental y se presentaban en las fiestas vestidos con sombreros, bastones y guantes. Las mujeres, por el contrario, mantuvieron su identidad visible hasta nuestros días" (Barragán 53). Her description coincides exactly with that we see in the group portrait, and adds a cohesiveness to the different subgroups. The cholas embody the site of urban indigeneity, as it were, and they lend this characteristic to the men and to the children, who are dressed in a way that makes them indistinguishable from the dominant creoles. The portrait when circulated must therefore emit the sense of the pollera and what it means about indigeneity in the city as a shared heritage among all the sitters.

Other images include the pollera among a gamut of signs and symbols that refer to indigeneity, even as they exceed it, in the articulation of a belonging to a community and place. In the Cordero archive, portraits like image 4 abound. It pictures a large group, probably family and friends, posing during an event such as carnival or some other festivity, as suggested by the scattered streamers and the relatively fancy clothes. The image also contains, like image 3 , the joining of modern male dress with the female pollera and bowler hat we have seen in other portraits. Importantly, and in consonance with this power of acquisition reflected in the elaborateness of their dress, it also prominently features their capacity to acquire entertainment: beer bottles are front and center, as are guitars, a bandoneon, and a charango or small guitar. Presumably, that entertainment leads to the varying levels of enjoyment visible on a large number of the faces, men, women and children alike. Smiles in portraiture were not the norm during the period. However long these sitters have been in La Paz, the image communicates that they have made of the city a space in which they will practice a culture of their own. 


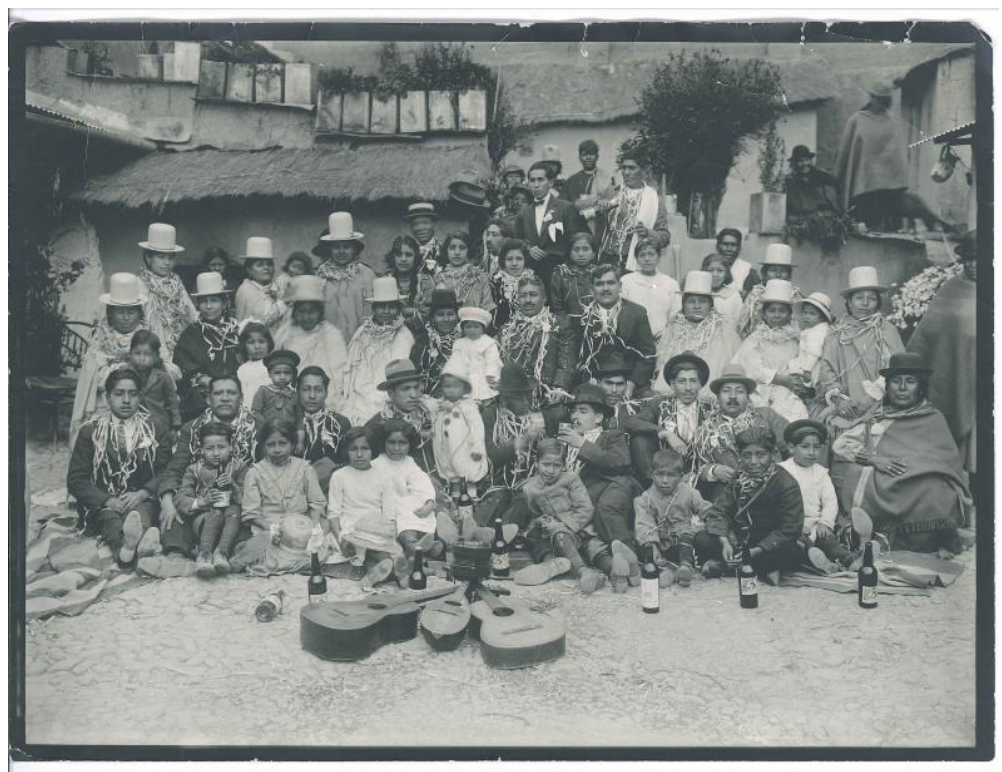

Image 4: Julio Cordero, La Paz, circa 1930

\section{Source: Cordero Archive}

The question arises concerning the degree to which pictured subjects had a hand in creating their representations of self. Cordero's extremely rich archive provides some evidence concerning this. In portraiture, the choices made in the presentation of the body and face are determinant of the practice itself. These can happen before or at the moment the picture is taken, but interventions can also be made in a portrait after it has been fixed to a physical support, such as cardboard.

In March 2011, I had the opportunity to spend a couple of weeks in the Cordero archive in La Paz. At that time, as perhaps it still is now, it was located in the family home in the neighborhood of San Pedro. Cordero's grandson, who oversaw the archive, asked me why, with so many photographs to review, I spent such significant amounts of time looking at the written materials in the archive. In part, the response to that question has to do with documents such as the letter cited below, which is written by a client from Santa Cruz and directed to his sister, one Dora S. de Hurtado P. in the city of La Paz in 1941. 
The buyer-his name cannot be found-writes concerning a memorial photograph for his recently deceased fiancée. The photographer they refer to is Cordero, and the image mentioned is in all likelihood of his making:

Ella [la imagen] sí adolece de alguna imperfección, como anotas tú, pero que es susceptible de salvarla.- I, para que puedas darle [al fotógrafo] una versión más exacta de sus facciones, como de los defectos que deben corregirse, te la devuelvo adjunta; los detalles que te encarezco darle, serían los siguientes que se hallan señalados:

1. El lado derecho de la faz, en la parte inferior, quitarle e igualarle con el otro lado (izquierdo).

2. Perfeccionar la boca, y que esta aparezca cerrada (recogido el labio inferior).

3. Las cejas, mas curvas y perfectas.

4. Darle una expresión más viva a los ojos, sin que pierda su languidez (porque eran así tristes).

5. Quitar la imagen de la derecha, asi como el fondo (blanquear) y más negro y brillante el cabello, algo ondulado como era.

6. La foto si puede ser tamaño postal, mucho mejor y de medio cuerpo.

Con todos estas perfecciones que se trata de hacer, de acuerdo con estas indicaciones, podría lograrse una imagen "viva" como para conservarla en forma que valga la pena, siendo un motivo de triple recuerdo: tuyo, de ella, y del artista que reavivará sus rasgos tan nítidamente. [sic]

The overexuberant directions that the letter communicates are meant to perfect the preexisting image, which is likely taken from a smaller, ID-type portrait. The letter is only rare in that it captures such desire in written form. The modification of images, ranging from the embellishment with colored paint, to the whitening of faces and the touching up of features is quite common, as image 5 illustrates. I stress that managing such desire must have been a daily, constant negotiation between Cordero and his subjects, as reflected in the diversity of poses and organization of studio portraits themselves, as well as in interviews and other documents. 


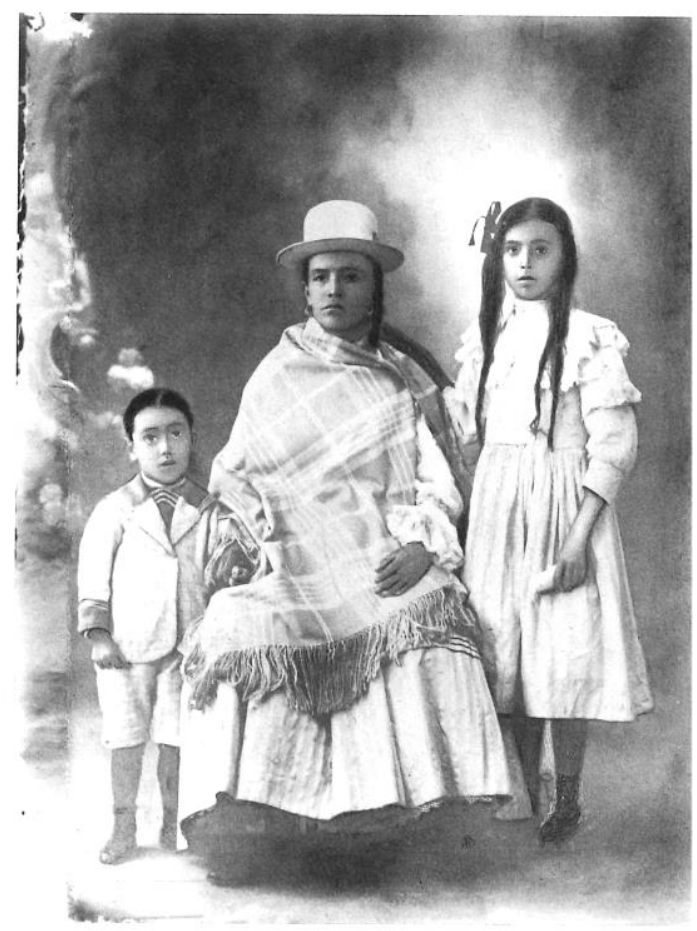

Image 5: Julio Cordero, La Paz, circa 1930

Source: Cordero Archive

Thus a photographic portrait should be understood as that site where at least two actors embark on a marrying of wills, technical know-how, and financial exchange. Image 5 patently documents these three factors. It also makes clear that the intervention in photographs after they are taken can vary greatly in terms of its effect. Image 5 has been modified by Cordero not only to whiten the skin, including faces and limbs, of the sitters, but also to modify the facial features themselves. The three subjects, presumably a mother with her two children, take on the eerie appearance of sitters wearing disguises. While the hand of the modifier seems expert, particularly in that it has maintainedor created? - a resemblance among the three, the effect is masklike. The faces 
seem less photographed than they do hand-designed. Indeed, a purposeful disconnection or depersonalization seems to be at play here. One of the fundamental functions of portraiture, that of recognition, is eschewed in this image. That is, the will to assume a different, reracialized appearance of this family, presumably toward more coveted features and skin color, likely results in a disconnect between image and bearer. Nevertheless, the portrait emphasizes for us the idea that self-image is constituted through a constant process of asserting the coincidence of the pictured with a subject at a particular moment in time.

Thinking about photographic portraits not simply as a field of representation but as a complex business, it would not be an exaggeration to say that Cordero's long encounter with photography was transformational for him professionally as well as personally. His great success at a relatively new business allowed him to ascend socially. That ascent, in this and other cases, demonstrates the flexibility of racial and ethnic identities in the Andes and the destabilization of social and economic hierarchies that were introduced by modernization. Cordero himself stands as an illuminating example of why considering the intersection of business with history and society allows us to better understand the possibilities and limitations of photography at the time.

As we have described, Cordero worked mainly in La Paz and was independent from 1898 until his death in 1961. According to interviews with his grandson, Cordero came from the town of Pucarani in the province of Los Andes and was brought to the city by his father in order to find a profession. In 1896, he was apprenticed in a photography studio run by two Peruvians, the Valdez brothers. By 1900, he had established his own studio on the calle Recreo in La Paz. Importantly, this studio also sold photographic equipment and supplies to other photographers as well as to the general public. His first years as an independent businessman seem to have been extremely successful. By 1904 he had moved to a new location in central La Paz on the calle Ayacucho. This studio had a very showy presence in the Edificio Sinfónico. The studio doubled as a store for photographic wares. Not only was his studio located in central La Paz on one of its most transited streets, it also occupied an ornate storefront that was sure to attract passersby as suggested by the centrality of the location and the facade in publicity from the period.

The long years of Cordero's active practice are marked by his work in studio photography. Many are the records of portraits being taken, and the extant photographic images back up the written records. But what is perhaps 
most striking about the records is that they demonstrate the profile of a savvy, aggressive businessman who was constantly and consistently looking for new ways to improve his presence in the market and to gain from it. This will is demonstrated not only in the acquisition of new merchandise and the selling of it in the local market, but also in his penchant for contractual dealings in which the benefits to Cordero as well as others are clearly mapped out. I note here, at the risk of redundancy, that for Cordero photography meant that he would need to master and make beneficial to him the notion and action of commerce and also the letter of the law. If the extant documents are any indication, he did both successfully.

There are a variety of materials that document in detail the business side of his studio. For example, it is extraordinary to note that from December 13, 1920, to May 25, 1921, that is, about five months, Cordero's business made a total of $8,347.60$ bolivianos. The documents clearly indicate that this is the income from only the La Paz studio. Moreover, records from the period indicate that he would routinely send anywhere from US\$50 to \$250 to Eastman Kodak in Rochester, as well as to other companies. The generation of this wealth in the servicing of debt did not solely rely on the business of taking, printing, and selling portraits. Interestingly, a substantial part of Cordero's income stream came from the sale and distribution of photographic goods, such as film, chemicals, paper, and cameras, to other photography businesses and to amateur photographers in the region.

Cordero kept meticulous records detailing dates of sale, merchandise sold, as well as daily and monthly expenses. Furthermore, a seemingly complete collection of his correspondence indicates that his business network not only included cities such as Oruro and Cochabamba in Bolivia; it also expanded to international sites such as Chicago, New York, Geneva, Paris, and Berlin. In the Bolivian cities, he set up satellite studios presumably in order to increase his revenues. He seems to have purchased supplies from the foreign cities, which constantly solicited his business. Moreover, the volume of correspondence sent to and received from Kodak in Rochester, New York, is sizable. Cordero sought a significant amount of credit from Kodak, which readily gave it. There is also record of Cordero's payments to the same company, as I have noted above.

Given Cordero's lengthy career, the dates it encompasses seem to have cycled through more and less profitable moments. One clear indicator of this is the changing socioeconomic status of his patrons, which can be seen in 
comparing his early work to his later years. While portraits taken in the decade after 1900 have a high incidence of well-dressed, patrician, and phenotypically white sitters, photographs from around and after 1930 such as image 1 have a greater variety of subjects, and in particular include large numbers of women who would be identified as cholas as well as others with indigenous or mestizo features. At least in part, the transformation in the customer base of the business toward the middle class seems to have been due to greater competition and a driving down of prices, which in turn led to greater accessibility to the service. No doubt, studios such as Luis Gismondi's, a competitor of Cordero, were a factor in this. Cordero's grandson confirms these suspicions.

The comparison with Luis Gismondi is instructive in order to understand the contours of Cordero's own practice. Although they were photographers based in the same city and at the same historical moment, their work differs significantly. An Italian immigrant who arrived in La Paz in the early twentieth century, Gismondi set up his studio in that city in 1907. (Quejerazu Leyton) Alternatively, Mariaca Iturri, citing the Peruvian scholar of photography Adelma Benavente, notes that the photographer was of Italian descent but was Peruvian-born and hailed from the city of Lima. (Mariaca Iturri 16) Gismondi seems to have been primarily interested in cataloging urban space as well as natural surroundings. In some cases, this meant the Andean landscape and in others, it seems to have included the region's indigenous peoples. Portraits do not seem to have been, as was the case in Cordero, the focus of his work.

From the collection of images that Quejerazu Leyton has curated and indicated as representative, the quantity of landscape and city images in relationship to portraits demonstrates a clear preference for the former. Moreover, these seem to have been taken with the production of postcards in mind, an established way of profiting from images. From interviews with family members, we know that Gismondi spent long periods away from his La Paz studio taking photographs in the countryside. He seems to have returned to La Paz in order to replenish his supplies and most likely bought supplies from his competitor Cordero, since Gismondi was not in La Paz consistently enough to become a supplier himself. The presence of a variety of indigenous subjects in Gismondi's work only highlights their absence in Cordero's. Apparently, Gismondi went so far as to invite indigenous subjects into his studio, a practice that was at the very least frowned upon. (Gismondi) Where Gismondi sought out indigenous people with profit in mind, Cordero could not countenance that 
possibility for other reasons. In fact, the Cordero archive contains few images of rural indigenous subjects.

Presumably, Cordero's origins in an Aymara-speaking community in the rural provinces presented barriers to him in the socially stratified paceño population of the early twentieth century. It was not a society that valued indigenous culture or knowledge. However, as a rural indigenous person, Cordero nevertheless managed to gain a prominent position in the city, becoming district representative for his neighborhood and involving himself in a variety of municipal activities. Apparently, these contacts led to his becoming an official photographer for the local police. This work involved taking mugshots of criminals as well as portraits of the police themselves.

Socioeconomically, then, photography and the visibility that it afforded Cordero facilitated his ascent in a society that tended to fix subjects' social positions through a variety of mechanisms, centrally including race and ethnicity. As Cordero's grandson tells it, these restrictions were not lost on Cordero: his ambition to assure his place in respectable paceño society may have been at least partly responsible for his ban on the speaking of Aymara in the family home (Cordero Benavides). Certainly, this gesture of willful acculturation is not unusual in societies that conceive of particular races and cultures as inferior. In some sense, Cordero's persona as a photographer functioned as the fulcrum and lever with which he "overcame" his indigeneity.

Image 6 demonstrates the mechanism of that escape. It is a photograph as lesson. Very clearly, the lesson aims to make the photographic technology equivalent to the art of painting. This equivalency is attained by a simple gesture: the pointing of the finger. It is, for all its obviousness, elegant: the hand that is so essential to painting and almost superfluous to photography somehow articulates the two and becomes, in one fell swoop, valuable again in the modern era. But perhaps mostly important: it, as well as the representations of both art and technology, obscures the indigenous origin of the photographer, or makes it unimportant. 


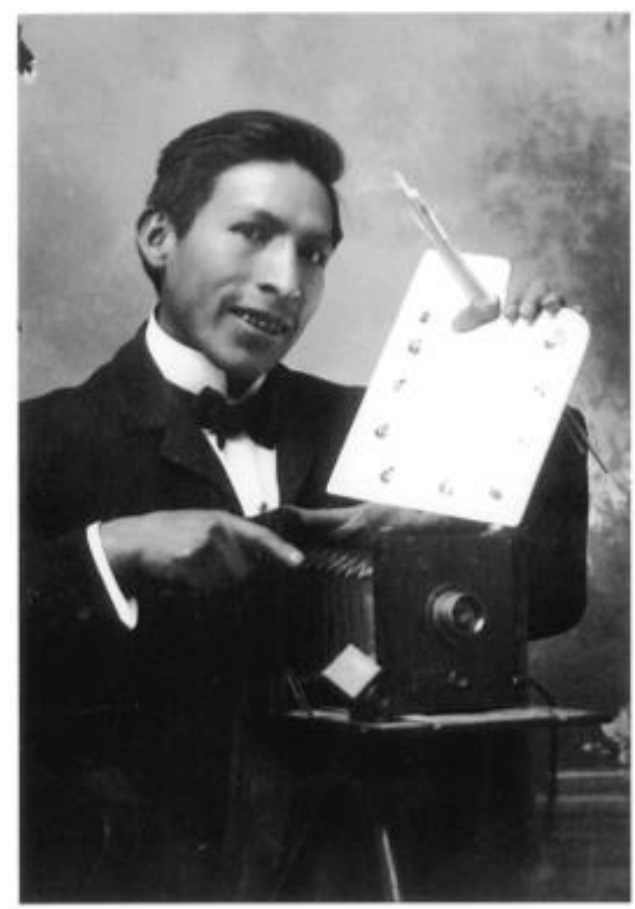

Image 6: Julio Cordero, La Paz, circa 1930 Source: Cordero Archive

Along with other portraits, both in and out of the studio, that are shown in this article, Cordero's autorretrato demonstrates how the body in conjunction with a technology of vision made available a way of inhabiting the modern moment in La Paz and the Andes. The varieties of self-representation commented upon here do not simply illustrate the range of responses in asserting a given subject's place in a particular society. Also and especially, they suggest that photographic portraiture was a powerful tool wielded through consumption and in a market in order to achieve that goal. It is difficult to think of an archive that better documents this idea and reveals its intricacies than Julio Cordero's. 


\section{Works Cited}

ANONYMOUS. 2013. "Alcaldía adquiere el archivo fotográfico de Julio Cordero." Página Siete. [https://www.paginasiete.bo/cultura/2013/10/16/alcaldiaadquiere-archivo-fotografico-julio-cordero-3306.html] downloaded Nov. 12, 2018.

BARRAGÁN, Rossana. 1992. “Entre polleras, ñañacas y lliqllas: Los mestizos y cholas en la conformación de la 'Tercera República.'” Tradición y modernidad en los Andes. Henrique Urbano, comp. Cusco: Centro de Estudios Regionales Andinos "Bartolomé de las Casas". 43-73.

CAZAS, Anahí. 2016. "Alcaldía elabora proyectos para abrir un teatro y una biblioteca." Página Siete.

[https://www.paginasiete.bo/cultura/2016/3/4/alcaldia-elabora-proyectospara-abrir-teatro-biblioteca-88669.html] downloaded Nov. 12, 2018.

CORDERO BENAVIDES, Julio. Personal Interview. March 15, 2011.

CORDERO, Julio. 2004. Estudio Archivo Cordero: Bolivia 1900-1961. Turner/Casa de América.

CORONADO, Jorge. 2018. Portraits in the Andes: Photography and Agency, 19001950. Pittsburgh: University of Pittsburgh Press.

DE CERTEAU, Michel. 1988. The Practice of Everyday Life. Steven Rendall, trans. Berkeley, Los Angeles, London: University of California Press.

DEBORD, Guy. 1994. The Society of the Spectacle. Donald Nicholson-Smith, trad. New York: Zone Books.

GISMONDI, Geraldine. Personal Interview. March 18, 2011.

HIRSCH, Julia. 1981. Family Photographs: Content, Meaning, and Effect. New York: Oxford University Press, 1981.

MARIACA ITURRI, Gabriel. Personal Interview. March 16, 2011.

POITEVIN, Guy. 2002. The Voice and the Will: Subaltern Agency: Forms and Motives. New Delhi: Manohar.

QUEREJAZU LEYTON, Pedro. 2009. Luigi Domenico Gismondi, un fotógrafo italiano en La Paz. La Paz: P. Querejazu.

SAAVEDRA, Milen. 2014. "En La Paz alistan la construcción del primer museo de fotografía." Página Siete.

[https://www.paginasiete.bo/cultura/2014/10/8/alistan-construccionprimer-museo-fotografia-34473.html] downloaded Nov. 12, 2018.

SUÁREZ, Hugo. 2005. "Archivo Julio Cordero (1900-1961): Fotografía del progreso en Bolivia." Relaciones 104 (XXVI): 107-133 


\section{$((c))$ EY} New articles in this journal are licensed under a Creative Commons Attribution 4.0 United States License.

UI D $D$-Sert This journal is published by the University Library System of the University of Pittsburgh as part of its D-Scribe Digital Publishing Program, and is cosponsored by the University of Pittsburgh Press. 